\title{
Investigation of metabolic disorders resembling Reye's syndrome
}

\author{
Anne Green, Susan M Hall
}

\begin{abstract}
Ten per cent of patients initially reported with Reye's syndrome in the British Isles (1981-91) were subsequently found to have an underlying inherited metabolic disorder (IMD). There was also evidence to suggest that other cases may not have been recognised. The range of metabolic disorders that mimic Reye's syndrome is wide and specialist, often complex, investigations are required to make a specific diagnosis. Those patients presenting with Reye's syndrome-like illness but also with one or more clinical features suggestive of an IMD require particular attention and detailed investigation. Recommendations for specimen collection and investigation are presented.
\end{abstract}

Reye's syndrome is a rare but serious disorder principally occurring in childhood, although adult cases have been described. ${ }^{12}$ Essentially it is an encephalopathy complicated by hepatic dysfunction, although there is increasing metabolic derangement as the illness progresses. Although the precise aetiopathogenesis is unknown, it is clear that preceding (prodromal) viral infection together with aspirin consumption are risk factors for initiating the cascade of events that culminates in Reye's syndrome. ${ }^{3}$ It is also believed that the fundamental site of the pathological process is the mitochondrion. ${ }^{4}$

It has become increasingly apparent that a significant number of patients who present with a Reye-like illness have an underlying inherited metabolic disorder (IMD). ${ }^{5}$ An infant or child with an IMD, particularly one of the disorders of fatty acid oxidation, may be completely well for months or years until a stressful event (for example prolonged fasting, infection) triggers a metabolic crisis which can present as a Reyelike illness; sodium valproate treatment has also been associated with precipitation of the illness. ${ }^{6}$ It is, therefore, essential that these patients are appropriately investigated, because there are implications both for management of the index case and for genetic counselling. For some IMDs prenatal diagnosis in future pregnancies and/or diagnosis in the neonatal period are available. Failure to investigate may be an important cause of misdiagnosis, especially in children under 3 years of age. ${ }^{7}$

We present our recommendations on which patients presenting with a Reye-like illness should be investigated for an IMD and on how to investigate.
Classical Reye's syndrome-clinical presentation and definition

The 'classical' clinical picture of Reye's syndrome is as follows: a previously healthy child, aged about 7-9 years, acquires a viral infection, typically of the upper respiratory tract (especially influenza) or chickenpox. A few days elapse, and there may even be some recovery, but then the child becomes unwell with frequent, effortless, profuse vomiting. The conscious level may deteriorate and range from lethargy or drowsiness, through hyperexcitahility and combativeness to deepening coma, often with convulsions. On admission, investigations will reveal increased hepatic transaminase (always), increased plasma ammonia concentration (usually), hypoglycaemia (in many cases, but not invariably), a prolonged prothrombin time (usually), normal plasma bilirubin concentration, and normal cerebrospinal fluid. There will be evidence of raised intracranial pressure and a liver biopsy specimen will reveal panlobular microvesicular fatty infiltration of hepatocytes with retention of nuclear position and no necrosis or inflammatory changes.

Electron microscopy of liver tissue will reveal ultrastructural changes, which are thought to be the only specific diagnostic markers of Reye's syndrome: proliferation of smooth endoplasmic reticulum, loss of glycogen, proliferation of peroxisomes and an alteration of hepatocyte mitochondria, including matrix expansion, loss of dense granules and the development of pleomorphic shapes. With progression to coma, these changes are accentuated. A population of clear cells appears, in which glycogen is diminished in granule size and in some cells is completely depleted. Mitochondria become large, with a progressively disrupted matrix. In children who survive 4-5 days after admission to hospital the liver injury appears to resolve, with restoration of glycogen stores and return of mitochondria to a normal appearance. Skeletal muscle shows abnormal lipid accumulation, glycogen depletion and mitochondrial injury in certain fibre types, but not all. ${ }^{4}$

The above description of a typical case embodies a range of both clinical and pathological features, the establishment of some of which, especially by electron microscopy, is constrained by the availability of technical resources and expertise within individual hospitals. For epidemiological surveillance purposes the case definition of Reye's syndrome has to be practical and simple and this inevitably

\author{
Correspondence to: \\ Mrs Green. \\ Accepted 20 June 1992 \\ Public Health \\ Communicable Disease \\ London \\ Susan M. Hall
}


compromises specificity for the sake of sensitivity. The definitions for Reye's syndrome used by the national surveillance schemes in the USA and in the British Isles are similar and the British one is as follows. A child under 16 years with unexplained non-inflammatory encephalopathy and one or more of:

(a) Serum hepatic transaminase increased $\geqslant \times 3$ upper limit of normal

(b) Plasma ammonia concentration increased $\geqslant \times 3$ upper limit of normal

(c) Characteristic fatty infiltration of liver (biopsy or necropsy).

\section{Surveillance of Reye's syndrome}

The British Reye's Syndrome Surveillance Scheme (BRSSS) began its activities in August 1981 and has now been maintaining a 'watching brief' over the occurrence of Reye's syndrome in the British Isles for just over 10 years. ${ }^{3}$ It was a joint venture of the British Paediatric Association and the Public Health Laboratory Service Communicable Disease Surveillance Centre. The initial 'passive' method of reporting was enhanced in mid-1986 by transferring to the 'active' system of the British Paediatric Surveillance Unit (BPSU). ${ }^{8}$ Cases who die are also ascertained via arrangements with the appropriate offices responsible for each of the constituent countries of the UK and the Republic of Ireland (British Isles): copies of all death entries in children under 16 years where Reye's syndrome is mentioned as a cause are supplied in confidence to the surveillance scheme.

Cases conforming to the criteria shown above are reported mainly by paediatricians, who are then invited to complete a questionnaire collecting detailed epidemiological and clinical information, or to send copies of summaries and/or necropsy reports. Clinicians are asked to inform the scheme if there is subsequently a diagnostic revision; information on such a revision is also actively sought by the scheme if there is concern about the validity of the diagnosis based on the initial information provided. Furthermore, general practitioners are contacted 6-12 months later to determine both outcome and whether the diagnosis has been changed.

Table 1 shows the annual total numbers of reports from 1981/2 to $1990 / 1$; it also shows the

Table 1 Reye's syndrome in the British Isles. Cases with follow up reported between 1 August 1981 and 31 fuly 1991

\begin{tabular}{|c|c|c|c|c|}
\hline \multirow[t]{2}{*}{$\begin{array}{l}12 \text { month period } \\
\text { (August-fuly) }\end{array}$} & \multirow[t]{2}{*}{$\begin{array}{l}\text { Total reports } \\
\text { British Isles }\end{array}$} & \multicolumn{2}{|c|}{$\begin{array}{l}\text { Classified as } \\
\text { Reye's } \\
\text { syndrome* }\end{array}$} & \multirow[t]{2}{*}{$\begin{array}{l}\text { Revised } \\
\text { diagnosis (\%) }\end{array}$} \\
\hline & & $\overline{N o}$ & Ratef & \\
\hline $\begin{array}{l}1981 / 2 \\
1982 / 3 \\
1983 / 4 \\
1984 / 5 \\
1985 / 6 \\
1986 / 7 \\
1987 / 8 \\
1988 / 9 \\
1989 / 90 \\
1990 / 1\end{array}$ & $\begin{array}{l}47 \\
69 \\
93 \\
64 \\
53 \\
47 \\
44 \\
31 \ddagger \\
24 \ddagger \\
25\end{array}$ & $\begin{array}{l}40 \\
59 \\
81 \\
56 \\
40 \\
26 \\
32 \\
18 \\
15 \\
13\end{array}$ & $\begin{array}{l}0.31 \\
0.46 \\
0.63 \\
0.41 \\
0.31 \\
0.20 \\
0.25 \\
0.14 \\
0.12 \\
0.11\end{array}$ & $\begin{aligned} & 7(15) \\
& 10(14) \\
& 12(13) \\
& 8(13) \\
& 13(25) \\
& 21(45) \\
& 12(27) \\
& 12(39) \\
& 8(33) \\
& 12(46)\end{aligned}$ \\
\hline Total & 497 & 380 & & 115 \\
\hline
\end{tabular}

* Satisfied diagnostic criteria, diagnosis not revised.

tPer $100000<16$ years of age.

fDetailed information not available for one case. numbers of patients who were subsequently ascertained as having had a diagnostic revision. After a peak of 93 total reports in 1983/4 there was a decline to a total of 25 in 1990/1, of whom 12 were subsequently reclassified.

\section{Inherited metabolic disorders}

The largest category of 'revised diagnoses' was IMDs-they accounted for over $40 \%$ of these cases (10\% of total Reye's syndrome reports) and are detailed in table 2 . This table also shows that three quarters of these were diagnosed in the most recent six years of the surveillance scheme. The commonest IMD identified was medium chain acyl coA dehydrogenase deficiency (MCAD). Organic acid disorders and urea cycle disorders were also significant groups.

There were nine patients in whom a metabolic disorder was strongly suspected (on clinical and biochemical grounds), but a definitive diagnosis was not reached. Of these nine, two had died and no investigations for an IMD had been undertaken but the diagnosis was suspected because of a history of a Reye-like illness in a sibling who had died. In one case there had been previous episodes of a Reye-like illness. Two patients died suddenly and unexpectedly in infancy and the diagnosis was suspected because of a fatty liver on histological examination, although material was not examined for an IMD. Three patients were undergoing detailed investigation because of clinical suspicion of an IMD: in two the results were not available at the time of reporting, whereas in the third the findings were not diagnostic of any known defect, although a disorder of $\beta$ oxidation was suspected. There was no detailed information on the remaining case.

Among the six patients in table 2 with a suspected organic acid disorder, no detailed information beyond the initial abnormal findings in blood or urine which led the clinician to revise the diagnosis of Reye's syndrome, was available at the time of reporting.

The group 'classified as Reye's syndrome' (table 1) are those who are not known to have had a revision, although it is likely that they included

Table 2 Revised diagnoses (Reye-like illnesses) 1981/2-1990/1 (1 August-31 fuly)*

\begin{tabular}{|c|c|c|}
\hline & \multicolumn{2}{|l|}{ Total } \\
\hline & $\begin{array}{l}1981 / 2- \\
1990 / 1\end{array}$ & $\begin{array}{l}1985 / 6- \\
1990 / 1\end{array}$ \\
\hline $\begin{array}{l}\text { Fatty acid oxidation defects (mainly } \\
\text { MCAD) }\end{array}$ & 20 & 17 \\
\hline Organic acid disorders & 6 & 5 \\
\hline Propionic acidaemia & 2 & 1 \\
\hline Ornithine transcarbamylase deficiency & 5 & 1 \\
\hline Primary carnitine deficiency & 1 & 1 \\
\hline Glutaric aciduria type II & 1 & - \\
\hline Glycerol kinase deficiency & 1 & 1 \\
\hline$\left(\alpha_{1}-\right.$ Antitrypsin deficiency & 1 & -1 \\
\hline $\begin{array}{l}\text { Fructose-1, 6-diphosphatase deficiency } \\
\text { Methylmalonic acidaemia }\end{array}$ & 1 & 1 \\
\hline Methylmalonic acidaemia & 1 & 1 \\
\hline Pyruvate dehydrogenase deficiency & 1 & 1 \\
\hline Ethylmalonic adipic aciduria & 1 & 1 \\
\hline Inherited metabolic disorder (NS) $†$ & 9 & 7 \\
\hline & 50 & 37 \\
\hline
\end{tabular}

"Inherited metabolic disorders were the single biggest group $(50 / 115=43 \%)$.

tNS = not specified-that is, strongly suspected clinically, but no definitive diagnosis. 
some IMD cases-either because a late revision was not ascertained or because such a diagnosis was not sought by the clinician.

It is of concern that, although all the 'revised' and 'non-revised' patients met the basic case definition for Reye's syndrome, the opportunity to be reclassified was somewhat 'hit and miss', depending at least partly on diagnostic awareness and probably, in some cases, on availability of resources and access to expertise in diagnosing IMDs. Many in the 'non-revised' group were very young infants with atypical Reye's syndrome (for example no clear prodrome, minimal or no vomiting, very sudden onset) and some even had suggestive past medical or family histories (see table 3). There was another group who died suddenly and in whom the diagnostic label of Reye's syndrome was applied by the pathologist on the basis usually of liver histology but occasionally only on the macroscopic appearance of the liver. Sometimes the histology reports in these patients were not typical of Reye's syndrome (for example inflammatory changes or necrosis present, fat globules macrovesicular or eccentrically dispersed).

The BRSSS findings have highlighted the overlap between 'true' Reye's syndrome (the type of classical case described above and which is now only rarely occurring) and the 'metabolic masquerader'. They also suggest that there may be serious under diagnosis of these IMD among children presenting with Reye-like illnesses.

\section{Investigation of children with Reye-like illness for IMDs}

Although as yet no specific underlying metabolic abnormality has been identified in classical Reye's syndrome, the number of IMDs which could present with a Reye-like illness is large. It includes the disorders of organic acid metabolism, including fatty acid oxidation, and those of urea cycle, amino acid, and carbohydrate metabolism. There may be other disorders, for example defects of the electron transport chain which so far have not yet been reported to cause an Reye's syndrome-like illness. Many of these metabolic disorders mimic Reye's syndrome, not only clinically and biochemically, but also histologically.

For diagnosis of an IMD it is essential that appropriate specimens, especially urine and blood, are taken at the right time particularly if the infant/child is likely to die and that the case is discussed with the local clinical chemist. Without these important fluids, ideally collected premortem, tissue specimens taken at necropsy may be useless and a diagnosis may be missed. Table 3 Features suggestive of an IMD in a child
presenting with a Reye-like illness

The presence of at least one of the following should stimulat detailed and careful discussion of investigation for an IMD:

(1) Young age ( $<3$ years) at onset of Reye-like illness

(2) Past history of: encephalopathic episodes; vomiting in association with viral infections; unexplained failure to thrive; neurodevelopmental disorder; 'near-miss' sudden infant death syndrome (SIDS)

(3) Family (both immediate and extended) history of: 'Reye's syndrome'; unexplained encephalopathy; SIDS

(4) Absence of history of a viral prodrome clearly separated from the onset of encephalopathy
WHO TO INVESTIGATE

The possibility of an IMD should be considered in all patients who present with a Reye-like illness. The presence of certain features (table 3) are particularly suggestive of an IMD and such cases demand careful investigation. Detailed discussions with a specialist centre providing investigations for metabolic disorders will be necessary.

\section{Relevant history}

Information which is particularly relevant to the investigation for an IMD includes:

(1) Family history-If previous siblings have died or had similar illnesses, what investigations were undertaken and with what results?

(2) Previous medical history-(i) Has this child been investigated for an IMD previously (for example because of a pre-existing neurodevelopmental problem)? If so, with what results? (ii) was the child receiving any drugs, particularly sodium valproate, before presentation with Reye's syndrome? (iii) has the child had any previous episodes of illness that were unexplained, for example hypoglycaemia, fits?

\section{Current illness}

Was the Reye's syndrome presentation precipitated by any change in diet/prolonged fasting or other stress associated event?

HOW TO INVESTIGATE

Patients with a Reye-like illness in whom a metabolic disorder is suspected are likely to have been investigated with a variety of first line biochemical tests. In addition to liver enzymes (aspartate aminotransferase or alanine aminotransferase, alkaline phosphatase, and $\gamma$ glutamyltransferase) these should have included: blood glucose, acid-base status, urinary ketones, plasma ammonia, blood lactate (if there is an unexplained metabolic acidosis).

Results of these investigations provide important clues to a possible metabolic disorder. Severe and/or unresolving metabolic acidosis, hypoglycaemia, hyperammonaemia, and lactic acidosis are all features of IMD, although not specific. At this stage the clinical chemistry laboratory should be asked to store deep frozen any surplus plasma or urine already collected and note the date and time of all specimens collected.

In all cases where one or more of the supporting features for investigation for an IMD (table 3) are present, specimens should be collected for additional investigations. If suitable specimens are not already available, further specimens should be collected as soon as possible after the onset of the illness (ideally blood should be taken before any intravenous infusions, epescially glucose, are given).

The investigations required are detailed below; results are required urgently as certain IMD diagnoses may indicate specific treatment regimens/courses of action. If the child is likely to die before definitive results from the blood or urine tests are available it is necessary to 
perform more rigorous sampling-either premortem or as soon as possible after death (table 4).

\section{Initial specimens required}

Initial specimens should if possible be collected before any intravenous treatment.

(1) Urine: ideally $5 \mathrm{ml}$ but less is useful; this should be stored frozen $\left(-20^{\circ} \mathrm{C}\right)$ as soon as possible (no preservative required).

(2) Blood: ideally $5 \mathrm{ml}$ but minimum of $1 \mathrm{ml}$ is useful if more cannot be obtained-place 1 $\mathrm{ml}$ into a fluoride bottle and the remainder into a heparinised bottle. Store both plasma specimens frozen $\left(-20^{\circ} \mathrm{C}\right)$ and store packed red cells from the heparinised specimen deep frozen.

\section{Investigations required}

Investigations should be comprehensive to include all IMDs which could present in this way (table 5). Initial investigations should include:

(1) Urine: amino acids (qualitative) and organic acids by gas chromatography/mass spectrometry (essential to refer to a specialist centre).

(2) Plasma: amino acids (initially qualitative with quantitation if indicated).

In addition if there is hypoglycaemia a plasma sample (collected in fluoride) should be taken for 3-hydroxy butyrate, free fatty acids, and lactate. If there is a metabolic acidosis a plasma sample (collected in fluoride, table 4) should be taken for lactate.

Table 4 Emergency sampling requirements for biochemical analyses. If any of the specimens are taken after death, it is extremely important to record accurately both the time of death and when specimens were taken. Appropriate storage as detailed below is essential

\begin{tabular}{|c|c|c|c|}
\hline Specimen type & Specimen requirements & Storage & Comments \\
\hline Urine & $\begin{array}{l}5-10 \mathrm{ml} \text {; but less is useful. If the } \\
\text { sample is contaminated with } \\
\text { blood, centrifuge to remove cells } \\
\text { before storage }\end{array}$ & Store at $-20^{\circ} \mathrm{C}$ & $\begin{array}{l}\text { If no urine is available consider } \\
\text { bladder stab }\end{array}$ \\
\hline $\begin{array}{l}\text { Blood } \\
\text { plasma }\end{array}$ & $\begin{array}{l}5 \mathrm{ml} \text { in lithium heparin and } 1.0 \mathrm{ml} \text { in } \\
\text { fluoride. Separate plasma as soon } \\
\text { as possible }\end{array}$ & Store plasma at $-20^{\circ} \mathrm{C}$ & Cardiac puncture may be necessary \\
\hline whole blood & $\begin{array}{l}5 \mathrm{ml} \text { in EDTA (1-2 } \mathrm{ml} \text { is useful) } \\
\text { (Plastic tube for DNA studies) }\end{array}$ & Store as whole blood at $-20^{\circ} \mathrm{C}$ & \\
\hline Skin & $\begin{array}{l}\text { Sterility is of paramount importance. } \\
\text { About } 2 \text { mm cube (for detailed } \\
\text { procedure, see Green and Insley. } \\
\text { Place in suitable transport } \\
\text { medium (available from most } \\
\text { virology or cytogenetic } \\
\text { departments). In an emergency } \\
\text { sterile isotonic saline can be used: } \\
\text { Do not use agar }\end{array}$ & $\begin{array}{l}\text { If necessary store at }+4^{\circ} \mathrm{C} \text { before } \\
\text { despatch to laboratory: Do not } \\
\text { freeze }\end{array}$ & $\begin{array}{l}\text { Skin taken up to } 24 \text { hours } \\
\text { postmortem is likely to be viable } \\
\text { provided it is not infected }\end{array}$ \\
\hline $\begin{array}{l}\text { Tissues (liver, } \\
\text { heart } \\
\text { muscle, } \\
\text { skeletal } \\
\text { muscle) }\end{array}$ & $\begin{array}{l}\text { Two or three needle biopsy specimens } \\
\text { should be taken and immediately } \\
\text { placed in a plastic tube (suitable } \\
\text { for cryopreservation) and snap } \\
\text { frozen in liquid nitrogen or solid } \\
\text { carbon dioxide }\end{array}$ & $\begin{array}{l}\text { Store frozen as cold as possible, } \\
\text { preferably in liquid nitrogen or } \\
-70^{\circ} \mathrm{C}\end{array}$ & $\begin{array}{l}\text { Note: these specimens are for } \\
\text { biochemical analyses only- } \\
\text { appropriate fixed samples will be } \\
\text { required for histology }\end{array}$ \\
\hline $\begin{array}{l}\text { Cerebrospinal } \\
\text { fluid }\end{array}$ & $\begin{array}{l}1 \mathrm{ml} \text { clear fluid. If specimen is } \\
\text { bloodstained, centrifuge and store } \\
\text { supernatant }\end{array}$ & Store frozen $\left(-20^{\circ} \mathrm{C}\right)$ & $\begin{array}{l}\text { Cerebrospinal fluid useful for } \\
\text { diagnosis of certain disorders- } \\
\text { discuss with specialist laboratory }\end{array}$ \\
\hline
\end{tabular}

Table 5 Inherited disorders that may present as a Reye-like syndrome. (Note: This is not an exclusive list but includes those disorders that it is known may present as Reye's syndrome)

\begin{tabular}{|c|c|c|}
\hline Disorders & Supporting biochemical marker(s) & Diagnostic test(s) \\
\hline $\begin{array}{l}\text { (A) Organic acid disorders: } \\
\text { Propionic acidaemia } \\
\text { Methylmalonic acidaemia }\end{array}$ & $\begin{array}{l}\text { Metabolic acidosis } \\
\text { Abnormal urine amino acids especially } \\
\text { increased glycine. } \\
\text { Profound ketonuria } \\
\text { Note: significant hyperammonaemia } \\
\text { and lactic acidosis can occur in these } \\
\text { disorders }\end{array}$ & $\begin{array}{l}\text { Urinary organic acids } \\
\text { Fibroblast or tissue enzymes }\end{array}$ \\
\hline $\begin{array}{l}\text { (B) Fatty acid oxidation disorders } \\
\text { (including disorders of carnitine } \\
\text { transport) }\end{array}$ & $\begin{array}{l}\text { Hypoglycaemia } \\
\text { Absence of urinary ketones* } \\
\text { Abnormal urinary organic acids } \nmid \text { (for } \\
\text { example dicarboxylic acids) } \\
\text { Plasma carnitine abnormal ( } \uparrow \text { or } \downarrow \text { ) } \\
\text { Plasma free fatty acid: } 3 \text {-hydroxy- } \\
\text { butyrate ratio } \\
\text { Notes: }{ }^{*} \text { positive ketones do not exclude } \\
\text { these disorders; †can be normal }\end{array}$ & $\begin{array}{l}\text { Fibroblast or tissue enzymes } \\
\text { DNA studies }\end{array}$ \\
\hline $\begin{array}{l}\text { (C) Urea cycle disorders: } \\
\text { Ornithine transcarbamylase } \\
\text { deficiency (OTC) }\end{array}$ & $\begin{array}{l}\text { Respiratory alkalosis, }{ }^{*} \\
\text { Hyperammonaemia }+++ \\
\text { Abnormal urine and plasma amino } \\
\text { acids especially increased glutamine } \\
\text { and alanine } \\
\text { Increased urinary orotic acid } \\
\text { Note: }{ }^{*} \text { a metabolic acidosis does not } \\
\text { exclude this disorder }\end{array}$ & $\begin{array}{l}\text { Liver OTC } \\
\text { DNA studies }\end{array}$ \\
\hline (D) Disorders of pyruvate metabolism & $\begin{array}{l}\text { Hypoglycaemia } \\
\text { Lactic acid increased (urine, plasma, } \\
\text { cerebrospinal fluid) } \\
\text { Abnormal plasma and urinary amino } \\
\text { acids-especially increased alanine }\end{array}$ & $\begin{array}{l}\text { Tissue (liver/muscle) enzymes of } \\
\text { pyruvate metabolism and electron } \\
\text { transport chain } \\
\text { DNA studies }\end{array}$ \\
\hline $\begin{array}{l}\text { (E) Carbohydrate disorders: } \\
\text { Fructose-1, 6-diphosphatase } \\
\text { deficiency }\end{array}$ & $\begin{array}{l}\text { Metabolic acidosis } \\
\text { Hypoglycaemia } \\
\text { Lactic acidosis }\end{array}$ & $\begin{array}{l}\text { Liver fructose-1, 6-diphosphatase } \\
\text { deficiency }\end{array}$ \\
\hline
\end{tabular}


Additional tests may be required depending on results of the above investigations and therefore suitable samples, either as part of the initial specimen or as a repeat specimen, are required to be stored for this purpose. These include: plasma carnitine-1 $1 \mathrm{ml}$ heparinised plasma (total and esterified) stored deep frozen, urinary orotic acid-2 ml urine, stored deep frozen, and DNA analysis for MCAD defect $-2 \mathrm{ml}$ whole blood collected in EDTA and stored deep frozen.

\section{INTERPRETATION}

Investigation for IMDs requires considerable skill and expertise. In particular the definitive diagnosis of organic acid disorders can be very difficult even by those with considerable experience. It is unlikely that sufficient expertise is available at district level and reference to a regional/supraregional specialist centre is essential.*

Definitive diagnosis for many of these disorders requires enzyme measurement (usually in cultured skin fibroblasts/liver) or, more rarely, DNA analysis. This is particularly important for those families who would like the opportunity of prenatal diagnosis for subsequent pregnancies. For this reason it is essential to take appropriate tissue from the infant/child (table 4).

\section{Discussion}

The annual incidence of Reye's syndrome in the British Isles changed between 1981 and 1991 (table 1). The cause of this was probably multifactorial: the interval between $1981 / 2$ and $1985 / 6$ included the 'start-up' period of the surveillance scheme, when diagnostic and reporting awareness may initially have been low. The reason for the 1983/4 peak is unknown-it was not associated with any significant influenza activity that winter.

The steady decline in total reports from 1985/6 onward was almost certainly due, at least in part, to the public and professional warnings about aspirin in June 1986, followed by withdrawal of paediatric aspirin formulations and warning labelling on all aspirin containing products. ${ }^{3}$ The decline particularly involved the classic cases of Reye's syndrome, an observation associated with a near halving of the median age of cases reported after 1986 compared to the earlier years.

${ }^{*}$ Holton JB. UK directory of laboratories diagnosing inborn errors of metabolism. 4th Ed, 1991. (Obtainable from Dr Holton, Biochemistry Department, Southmead Hospital, Westbury on Trym, Bristol BS10 5NB).
Another possible cause of the decline in reported Reye's syndrome, particularly in recent years, was increased diagnostic awareness of the IMDs that mimic it and their recognition before the cases were reported.

It is likely that IMDs currently poorly defined or possibly new disorders will be described as causes of a Reye-like illness in the future. The importance of storing patient material (that is urine, plasma, whole blood, and tissues) from deceased cases who are strongly suspected of having an IMD, but in whom a definitive diagnosis has not be made, cannot be over emphasised.

The BRSSS data show that just under half (44\%) of the patients who presented with a Reye-like illness between 1987 and 1991 were managed solely at their local district hospital and therefore there is a need for the general paediatrician and the local clinical chemist to be aware of the need for these specialist investigations, and to ensure appropriate specimen collection and storage. There is also a need for increased diagnostic awareness among pathologists-particularly those conducting postmortem examinations on patients with sudden unexpected death in infancy. Dialogue with a specialist centre for the investigation of metabolic disorders is of paramount importance in all suspected cases.

Reye's syndrome is rare but undoubtedly cases of metabolic disorders are being under diagnosed as a consequence of inappropriate or inadequate investigation. The possibility of an IMD should be considered in all patients who present with a Reye-like illness, but particularly those who are of young age and/or have a positive past/family history.

Thanks are due to all BPSU respondents on whose goodwill the success of the reporting scheme depends, especially to those who reported patients with Reye's syndrome and provided detailed follow up information. The unit is funded by a grant from the Medical Research Fund of Children Nationwide. We also thank Lisa Newton for meticulous project administration.

1 Reye RDK, Morgan G, Boner J. Encephalopathy and fatty degeneration of the viscera, a disease entity in childhood. Lancet 1963;ii:749-52.

2 Ede RJ, Williams R. Reye's syndrome in adults [Editorial] BM J 1988;296:517-8.

3 Hall SM. Reye's syndrome and aspirin: a review $\mathrm{Br}$ F Clin Pract 1990;44:4-11.

4 Partin JS. Ultrastructural changes in liver, muscle and brain in Reye's syndrome. In: Wood C, ed. Reye's syndrome. London: Royal Society of Medicine, 1986: 1-20.

5 Robinson RO. Differential diagnosis of Reye's syndrome. Dev Med Child Newrol 1987;29:1110-20.

6 Kuhara T, Inoue Y, Matsumoto M, et al. Altered metabolic profiles of valproic acid in a patient with Reye's syndrome. Clin Chim Acta 1985;145:135-42.

7 Forsyth BW, Shapiro ED, Horwitz RI, Viscole CM Acampora D. Misdiagnosis of Reye's-like illness. Am $\mathcal{J} D$ is Acampora D. Misdiag

8 Hall SM, Glickman M. The British paediatric surveillance unit. Arch Dis Child 1988;63:344-6.

9 Green A, Insley J. Technique of skin biopsy. In: Insley J, ed $A$ paediatric vade-mecum. 12th Ed. London: Edward Arnold, 1990:273-4. 